\title{
Challenges and technologies of care developed by caregivers of patients with Alzheimer's disease
}

Melanie Scheneider Schmidt ${ }^{\top}$ Melissa Orlandi Honório Locks² Karina Silveira de Almeida Hammerschmidt ${ }^{3}$ Darla Lusia Ropelato Fernandez ${ }^{3}$ Francisco Reis Tristão $0^{2}$ Juliana Balbinot Reis Girondi²

\section{Abstract}

Objective: to identify the challenges and technologies of care developed by caregivers of patients with Alzheimer's disease. Method: an exploratory study with a qualitative approach was carried out with nine caregivers of elderly people with Alzheimer's disease from the mutual help group of a university hospital in the south of Brazil. Data collection took place between May and August 2017 through a semi-structured interview. Content analysis was used to analyze the data. Results: two categories emerged from the analysis of the data: the challenges faced by caregivers of elderly people with Alzheimer's Disease and the care technologies developed by caregivers of elderly people with Alzheimer's disease. Conclusion: the study showed that the care strategies elaborated by the caregiver can enhance understanding, reflection and discussion among health professionals, caregivers and family members about quality care for the elderly and minimize the difficulties of care in order to provide greater quality of care for the elderly.

\footnotetext{
1 Universidade Federal de Santa Catarina, Programa de graduação em Enfermagem. Florianópolis, Santa Catarina, Brasil.

2 Universidade Federal de Santa Catarina, Departamento de Enfermagem, Programa de pós-graduação em Gestão do Cuidado em Enfermagem. Florianópolis, Santa Catarina, Brasil.

3 Universidade Federal de Santa Catarina, Departamento de Enfermagem, Programa de pós-graduação em Enfermagem. Florianópolis, Santa Catarina, Brasil.

Keywords: Elderly. Alzheimer Disease. Caregivers. Aging. 


\section{INTRODUCTION}

Alzheimer's disease (AD) is the most common form of dementia in the elderly, accounting for $50 \%$ to $70 \%$ of cases. However, although one million people have this pathology in Brazil, there remains little data regarding its incidence in the country ${ }^{1}$.

Due to its degenerative nature, the disease impairs the individual's ability to perform activities of daily living (ADL) and instrumental activities of daily living (IADL) ${ }^{2}$. Considering the progression of the disease, caring for elderly persons with $\mathrm{AD}$ presents diverse and complex challenges for caregivers ${ }^{3}$.

When a family member cares for an elderly person with $\mathrm{AD}$, the negative points of this role (anxiety, depression, among others) often become issues, along with the caregiver's own dissatisfaction ${ }^{4}$. Faced with these challenges, many caregivers use creativity and adopt and/or employ various technologies in order to improve and facilitate the care process, as they experience the pre-eminent need for the multiple adaptations that the disease brings with it.

Technology is understood here as a set of knowledge and actions applied to the production of something, which in the case of the study in question, are technologies for the production of care ${ }^{5}$.

The present study therefore aimed to identify the challenges and technologies of care developed by caregivers of patients with Alzheimer's disease.

\section{METHOD}

An exploratory, qualitative study was carried out with caregivers of elderly people with $\mathrm{AD}$ who were participants of the Mutual Assistance Group (MAG) of the Brazilian Alzheimer's Association (ABRAZ) in Florianópolis, Santa Catarina, of the Hospital Universitário Professor Polydoro Ernani de São Thiago. The group is a non-profit association with the objective of disseminating knowledge about AD through the guidance of health professionals and the experiences of caregivers. The group involves activities that extend from the welcoming of new caregivers through discussion groups and informative meetings, with these activities intercalated on a weekly basis.
The group was chosen as a study scenario as it brings together a significant number of participants and also because it is where the interest for the research emerged from the questions and exchanges of experience among the participants regarding the care technologies they implemented.

The study population consisted of all the participants, family members and caregivers of elderly people with Alzheimer's who attended the MAG at the time of data collection and who met the inclusion criteria, which were: be a caregiver of an elderly person with Alzheimer's, aged over 18 years and attend or have attended the group in the last year, regardless of the number of meetings attended. The exclusion criteria were: live outside the Greater Florianópolis region, making home visits impossible. The caregivers were invited to participate on the days of the meetings of the group and by telephone contact. After acceptance, the meetings were held at a location chosen by the caregiver. Therefore, some were performed in the room where the group took place while others were carried out in the home. All the participants signed a Free and Informed Consent Form (FICF) and retained a copy of the same.

Data collection took place through semistructured interviews between May and August 2017, conducted by a single interviewer who was not part of the mutual aid group. The questionnaire was composed of two stages, the first of which contained information about the profile of the elderly persons and the second which contained open questions regarding the specific daily care of the elderly including diet, hygiene and comfort and medication, among others. Nine caregivers participated. To guarantee their anonymity, the participants were identified with the codenames C1 to C9.

The data analysis followed the steps established by Content Analysis: pre-analysis from a skim reading and establishing of the corpus; exploration of the coded material from the dividing of the texts into register units; and treatment and interpretation of the results obtained through working with meanings of the data ${ }^{6}$.

The information collected through interviews with the caregivers of elderly persons with AD was employed in the pre-analysis phase. This was 
transcribed and analyzed qualitatively from an analytical perspective through the skim reading of the investigated material. The corpus for analysis was therefore obtained. In this process it was necessary to constantly return to the initial questions.

During the exploration of the coded material, the significant expressions from the interviews, upon which the contents of the speech were organized, were identified. In this way, the units of meaning (UM) where the key words, sentences and phrases were codified were extracted from the text. After the identification of the UM, through a counting process based on the codifications, the classification and aggregation of the data was performed. Theoretical synthesis categories were then created to specify the theme ${ }^{6}$.
The treatment and interpretation of the results phase involved the condensing and highlighting of the information for analysis, culminating in inferential interpretations, at the moment of intuition, of the reflexive and critical analysis ${ }^{6}$.

The study was approved by the Ethics Committee on Research Involving Human Beings of the Universidade Federal de Santa Catarina under number CAAE 65869817.4.0000.0121.

\section{RESULTS}

The participant caregivers were aged between 52 and 70 years with a mean of 61 years and their main characteristics are listed in Table 1.

Table 1. Characterization of participants ( $\mathrm{N}=9)$. Florianópolis, Santa Catarina, 2017.

\begin{tabular}{lll}
\hline Categories & Characteristics & Characteristics \\
\hline Family Caregiver (8) & Spouse (1) & Son/daughter (7) \\
Occupational Caregiver (1) & Professional training $(-)$ & No professional training (1) \\
Gender of caregiver (9) & Female (8) & Male (1) \\
\hline
\end{tabular}

Two categories emerged from the analysis of the data: challenges faced by caregivers of elderly people with Alzheimer's Disease and care technologies developed by caregivers of elderly people with Alzheimer's disease.

Challenges faced by caregivers of elderly people with Alzheimer's disease

This category describes the difficulties of caregivers regarding the daily care of elderly people with AD in terms of ADL and IADL.

In relation to sleep and rest, difficulties were observed in maintaining regular and peaceful sleep, in addition to difficulties to either falling asleep or waking up early. In addition, it is common for the elderly to experience restlessness at dusk.

"He didn't sleep for almost fifty hours. Sometimes he has bad turns... Then he talks all the time and I have to stay close to him. It's bad for him because he needs sleep and bad for the people who need to sleep too" (C9).

“[...] it's worse from six o'clock in the evening she starts shouting, saying things, sometimes she's anxious, there's a despair inside her that I worry about, but I think it's her illness" (C4).

Regarding the care of hygiene and comfort, the caregivers reported that most of the elderly are resistant to bathing and have difficulties wearing the appropriate clothing for the seasons, mainly due to forgetting the stages of these procedures. In oral hygiene the greatest difficulty is closing the lips.

"Bathing is terrible, bathing has always been the most complicated issue. She even gets up, takes medicine, drinks coffee, but she doesn't want to have a bath, she doesn't want to change her nightclothes, she doesn't want to. She curses me and beats me, she asks for help ... so imagine what it's like between us" (C7). 
“[...] She hasn't even brushed her teeth lately. She won't let me, she won't open her mouth! I'm scared she has caries, because how can we fix them?" (C6).

In care related to the intake of food and liquids, the caregivers emphasized the slowness of the process, the difficulties of chewing and/or swallowing and a trend towards a greater intake of sweet foods. It is also necessary to change the consistency of food, which needs to be liquefied.

"She doesn't chew, so all the food has to be put in a blender [...]" (C2).

"Sometimes we make beans and rice, meat and some vegetables, put it in the blender, it gets creamier and she eats it slowly. And when I say slowly I mean one hour. It takes an hour, and most of the time she doesn't eat savoury foods" (C5).

In terms of the cognitive disorders of the demented elderly, the caregivers emphasized: inability to perform IADL, recurrent loss of memory, awareness and, especially, value judgment.

"The hardest part of it is the way she hides things. Sometimes the girl who comes to clean in the morning finds a cleaning product because we have to keep the products, the floor cloth, the broom, everything in my sister-in-law's closet in the other house because otherwise she hides them" (C8).

"She doesn't interact anymore, I mean pain, thirst, heat, cold, anything. Her senses are gone. She does not talk either. She doesn't know me, she doesn't know her daughter. She just complains. I call her name, she looks and definitely thinks who is it, who is calling, in her subconscious. But I see that there is no way back" (C5).

Other important difficulties reported were difficulty in accepting and swallowing medications and aspects related to physical mobility.

"She spits, keeps the tablet in her mouth, I have to watch to see if she's really swallowed it, it's a lot of work!" (C7).

"She was lying on her side and I forgot to put the railing up and she fell. I do not know how she didn't hit her head. I turned her so she could rest and went inside to make food. I thought, my God I forgot my mother, and when I came back she was already on the floor. And she didn't move [...] she broke her femur" (C3).

The challenges faced by caregivers generate burden, meaning they eventually neglect their own self-care. In addition, the routine and demand for uninterrupted care associated with increased domestic activities generate physical and emotional exhaustion among caregivers.

"Most of my life is spent here. I've got everything here, I've put a sewing table here so sometimes I feels like sewing, but mostly I don't. I live here in the bedroom, I just go out to do something inside, get something to eat [...]" (C3).

"So that's why I left my family, I left everything there, I put my life in a drawer, I gave up university, and I came here to be with my dad" (C9).

\section{Care technologies developed by caregivers of elderly people with Alzheimer's disease}

This category addresses the main care technologies that were developed by caregivers of elderly people with AD, including: adaptation of the environment for the physical safety of the elderly; adaptations for care in relation to ADL and IADL; leisure activities.

Among the adaptations of furniture and/ or equipment identified, the most notable were: installation of support bars in the bathroom and the home; installation of spring doors; use of "busy or unoccupied" toilet signs; automatic faucets in the bathroom; widening of doors; removal of glass shower cabinets in bathrooms; toilet adapter; change of mattress to reduce bed height; safety boards such as side railings of the bed and use of safety gates; inflatable mattress for prevention of skin lesions.

"At first she locked herself in the bathroom. Then I put a spring on it, took out the latch, and then she couldn't get stuck. I put a spring to keep the door closed ... and I put a sign on the door saying it was either busy or unoccupied" (C5). 
"[...] they complained that we were wasting a lot of water. She left the tap on. I put on an automatic faucet. You press it, use it and it turns itself off $[\ldots] "(\mathrm{C} 5)$.

"We made a handrail so she could get from the bedroom to the bathroom, she can hold it with her hand, the toilet has a higher support, it has a special seat. It is about $10 \mathrm{~cm}$ higher to make it easier for her to sit down and get up" (C6).

In relation to the specific adaptations for maintaining the safety of the elderly, there were reports of removing carpets in the home, shutting off gas in the kitchen, installation of non-slip floors, use of protective belts with patches of fabric for mechanical restraint. Kitchen, matches, alcohol gel and door keys were also put out of reach of the elderly persons.

"After she started to mess with the oven and didn't know what she was doing I started to see that she lit the oven, and it exploded. This happened at home and so I started to close the kitchen door, turn off the gas, and not leave matches around [...]" (C7).

"My neighbor gave me pieces of string, and I tied her to the wheelchair though I disguised it [...]. Because one day I was at the market and I saw she was almost on the floor, she didn't fall, but she was slipping off the chair" (C2).

Food-related adaptations mentioned include: liquefying food; use of bottles and/or straws to facilitate and/or speed up the feeding process.

"She uses a baby's bottle because she can't chew [...] sometimes I even have to spoon feed her to stop her giving up" (C4).

Adaptations involved macerating in administering medicine involved macerating the tablets and combining them with food in order to make the elderly accept them.

"She doesn't swallow the pills or she spits them out, and then I have to give her more medicine. So I crush it all. I put it in water to break it down, to make it liquid, sometimes I give it to her pure, sometimes I mix it with food, with yogurt, or a dessert...” (C4).
There were noteworthy adaptations relating to hygiene and comfort among the caregivers, including: the creation of a toilet at the side of the bed; a blackout curtain or plastic sheet used as a waterproof sheet; the use of a bath chair or heater.

"She urinates in the toilet I made beside the bed" (C2).

"She bathes in the shower, there's a little chair that has a hole in the middle. So we use a heater, let the room warm up and then she takes a shower sitting down [...]" (C5).

The use of a geriatric diaper combined with a baby diaper was described to increase the absorption of urine; as was the use of underwear under the geriatric diaper and the application of ointment together with essential fatty acid to prevent dermatitis.

"I use a geriatric diaper with a baby diaper. I even used those big panty liners, but it was no use. I had to change the sheet every time as well because everything went through. It was terrible! Now I put it in in the morning and sometimes I only change the geriatric diaper at night. If not it's just the baby diaper. It's great!” (C3).

Leisure activities included: bingo, shopping trips and/or to beaches, watching television, listening to music, car rides, gardening and playing with dolls.

\footnotetext{
"She likes music, we always put it on to listen to, but there are days when she's not interested, it depends on the day. There are days when she dances, claps, and we see she's following the sound" (C6).

"[...]she started to ask the children. So I bought a doll' (C2).
}

The main technologies developed by the caregivers were: crossword games; jigsaw puzzles; clipping activities based on ADL and IADL; and the creation of games, including the association of image with writing and memory games.

"I made all the games, I used the catalogs for most of them. There are two identical catalogs so that I can play the game of pairs, of memory [...]. I managed to get a lot of materials. And so I managed to make a puzzle game, the game of pairs [...]" (C8). 


\section{DISCUSSION}

The profile of the interviewees is made up of family caregivers ( $\mathrm{n}=8$ ), most of whom were caring for parents $(n=7)$, female $(n=9)$, similar to those found in literature?

Dementia has an important impact on the family, caregivers, society and the economy ${ }^{8}$. The findings of the present study show that these difficulties are, in large part, linked to the maintenance of the basic human needs of the elderly by the caregiver.

Sleep disorder was one of the most frequently observed behavioral disorders. Literature suggests that, in general terms, such a disorder is due to changes in neuronal activity, interfering in the balance of the sleep-wake cycle and a reduction in cholinergic activity. In addition, difficulties in comprehension experienced during the day influence the sleep of the elderly with $\mathrm{AD}^{9}$. The behavioral changes common to dusk are explained in the literature as "sunshine syndrome" or "sundowning", characterized by mental agitation and/or confusion during the day, which was confirmed by the statements ${ }^{10}$.

The difficulty of the elderly person with $\mathrm{AD}$ in accepting hygiene and comfort care was also a challenge for caregivers. Studies indicate that due to memory impairment and learning and communication problems, elderly people with AD will inevitably exhibit difficulties in carrying out basic personal hygiene care.

Some research suggests that, in this condition, the responsibility of care is inextricably linked to the caregiver, making them responsible for the total or partial accomplishment or supervision of tasks, due to the complexity of the same being carried out by an elderly person with dementia ${ }^{11}$.

Most caregivers reported difficulty in care involving eating, highlighting the need to alter food consistency to facilitate this process.

Similar to the findings of the present research, a study that aimed to assess the risk of dysphagia and its relationship to the stage of Alzheimer's disease found that as AD progresses, the risks for the development of dysphagia increase ${ }^{12}$, which possibly explains the changes in the eating patterns of the elderly and even in the acceptance and administration of medications observed in the present study. It should be noted that this fact is related to the emergence of lingual motor dysfunction, delayed swallow reflex, reduced oral motor control and an inability to masticate, described in literature as frequent disorders in elderly persons with $\mathrm{AD}^{12}$.

The inability to perform IADL, recurrent loss of memory, loss of sensation and loss of value judgment was also observed in the study population, as mentioned by caregivers. Researchers describe how the anchorage of the elderly in the memories of the past represents a phenomenon of support of identity and the preservation of self-consciousness. In addition, due to these aspects, impaired reasoning and judgment are also observed in the elderly with $\mathrm{AD}$ and represent nursing problems that can be dealt with ${ }^{13}$.

Accordingly, care technologies constitute essential tools for maintaining/attempting to maintain cognition for as long as possible, with the aim of prolonging the social integration and attachment of the elderly ${ }^{13}$.

Another challenge described by the caregivers was the reduction of balance, gait and, above all, mobility among the elderly with AD. Literature emphasizes that these are conditions observed in the evolution of $\mathrm{AD}$, related to the occurrence of secondary outcomes such as a greater risk of falls ${ }^{14}$.

In addition, because of burden, there are frequent signs of anxiety and depression among caregivers, resulting in physical and emotional exhaustion in various contexts. On such occasions it is essential to recognize the importance of a broad and multidisciplinary approach based on the needs of caregivers so that they do not neglect their own self-care $e^{15}$.

Many technologies developed by the caregivers were related to adaptations of the home environment to maintain the physical safety of the elderly in order to preserve their functional capacity as much as possible, allowing them to perform ADL or certain tasks autonomously ${ }^{16}$. A caregiver can be one of the parties responsible for the publicizing and broadening of knowledge about the care of elderly persons with $\mathrm{AD}^{17}$, emphasizing the daily necessities of those with Alzheimer's Disease. 
This wide range of care technologies comprises a set of knowledge and actions applied to the production of something, which in the case of the study in question, are technologies for use in care ${ }^{18}$. Technologies can also be placed into categories such as hard technology, which corresponds to materials such as equipment and furniture; softhard technology, which includes knowledge related to the disciplines that work in the health area, such as dentistry, medical clinic, epidemiology, among others and soft technology, related to the production process of communication and human relations, among others ${ }^{19}$.

In this context, the concept of technology can be considered as a result of processes arising from people's everyday experiences, for the development of a set of knowledges and strategies in an organized and articulated manner, for the elaboration, planning and execution of material and symbolic goods with a specific practical purpose ${ }^{18}$, which in this case corresponds to the more efficient care of the elderly with AD.

The loss of hydration, oiliness and elasticity of the skin was also reported in this study, and occurs as a consequence of loss of mobility, increasing frailty and the ease of injury, one of which is pressure ulcers and/or skin tears - disruption of the skin mainly by friction and shearing ${ }^{20}$. For this, many caregivers use as alternative special paddings and wound coverings, such as a hydrocolloid dressing for the prevention and treatment of such skin lesions.

As for the care technologies developed for the hygiene and comfort of the elderly, caregivers used creativity to provide safety and well-being, mainly related to bladder and bowel movements, such as the development of a toilet adapted to the side of the bed, as depending on the phase of the disease the elderly person may be unable to remember their way to the bathroom, and even the use of geriatric diapers.

Urinary and intestinal incontinence is another common condition in elderly people with Alzheimer's as they lose the ability to recognize the need to go to the bathroom. However, incontinence may also be related to changes in the urinary tract during aging, even in the absence of dementia ${ }^{21}$.
As for leisure activities, most caregivers reported using music, walking and the development of games that stimulate cognition. Studies have shown that leisure activities tend to improve performance in ADL in elderly persons with $\mathrm{AD}$, as they trigger the activation of existing brain functions and delay cognitive decline by creating new connections between neurons.

Therefore, technology is associated with the way people live, and can be present in workplaces, homes and relationships, consisting of the human skills to build and use tools from an emerging need ${ }^{18}$. Health work cannot be expressed in structured technological equipment and knowledge, since its most strategic actions are in intervention processes, operating as technologies of relationships, encounters and subjectivities ${ }^{22}$.

In this way, the study showed that aging with $\mathrm{AD}$ demands numerous challenges, requiring caregivers to constantly learn and develop skills and creativity to exercise quality care and develop both adaptations and care technologies. Limitations of this study include its regional nature and the limited number of participants.

\section{CONCLUSION}

The main care technologies found in this study were adaptations of the home environment aimed at the physical safety of the elderly with Alzheimer's disease, as well as the use of suitable mattresses and covers for the prevention of pressure ulcers, such as hydrocolloid dressings at the pressure points of elderly persons with Alzheimer's disease, and the use of resources such as music, walking and leisure to stimulate the cognition of such individuals.

The caregivers showed themselves to be a great supporters of the care given that it is they who spend most of their time with the elderly, as well as being responsible for assisting them in carrying out activities of daily living in order to preserve their autonomy as much as possible. It is believed that the care technologies identified in this study can help other caregivers in the process of caring for the elderly with Alzheimer's Disease. 


\section{REFERENCES}

1. Falco A, Cukierman DS, Davis RAH, Rey NAR. Doença de Alzheimer: hipóteses etiológicas e perspectivas de tratamento. Quim Nova [Internet]. 2016 [acesso em 03 jun. 2018];39(1):63-80. Disponível em: http://www.scielo.br/pdf/qn/v39n1/0100-4042qn-39-01-0063.pdf

2. Talmelli LFS, Vale FACV, Gratão ACM, Kusumota LK, Rodrigues RAP. Doença de Alzheimer: declínio funcional e estágio da demência. Acta Paul Enferm [Internet]. 2013 [acesso em 03 jun. 2018];26(3):219-25. Disponível em: http:// www.scielo.br/scielo.php?script=sci_arttext\&pid $=$ S0103-21002013000300003

3. Ilha S, Backes DS, Santos SSC, Gautério-Abreu DP, Silva BT, Pelzer MT. Doença de Alzheimer na pessoa idosa/família: dificuldades vivenciadas e estratégias de cuidado. Rev Esc Anna Nery Enferm [Internet]. 2016 [acesso em 02 set. 2017];20(1):138-46. Disponível em: http://www.scielo.br/scielo.php?script=sci_arttex t\&pid=S1414-81452016000100138

4. Tristão FR, Santos SMA. Atenção ao familiar cuidador de idoso com doença de Alzheimer: uma atividade de extensão universitária. Texto \& Contexto Enferm [Internet]. 2015 [acesso em 03 jun. 2018];24(4):1175-80. Disponível em: http://www.scielo.br/pdf/tce/v24n4/ pt_0104-0707-tce-24-04-01175.pdf

5. Nietsche EA, Lima MGR, Rodrigues MGS, Teixeira JA, Oliveira BNB, Motta CA, et al. Tecnologias inovadoras do cuidado em enfermagem. Rev Enferm UFSM [Internet]. 2012 [acesso em 06 jun. 2018];2(1):182-9. Disponível em: https://periodicos. ufsm.br/reufsm/article/view/3591

6. Minayo MCS. O desafio do conhecimento. Pesquisa qualitativa em saúde. São Paulo: Hucitec Editora; 2014.

7. Gonçalves LTH, Leite MT, Hildebrandt LM, Bisogno SC, Biasuz S, Falcade BL. Convívio e cuidado familiar na quarta idade: qualidade de vida de idosos e seus cuidadores. Rev Bras Geriatr Gerontol [Internet]. 2013 [acesso em 05 jun. 2018];16(2):315-32. Disponível em: http://www. scielo.br/scielo.php?script=sci_abstract\&pid=S180998232013000200011\&lng=pt\&tlng=pt.

8. Steiner ABQJ, Jacinto AF, Mayoral VFS, Brucki SMD, Citero VA. Mild cognitive impairment and progression to dementia of Alzheimer's disease. Rev Assoc Med Bras [Internet]. 2017 [acesso em 06 jun. 2018];63(7):651-5. Disponível em: http://www. scielo.br/scielo.php?script $=$ sci_arttext\&pid=S010442302017000700651\&lng=en\&tlng=en
9. Scoralick FM, Camargos EF, Freitas MPD, Nóbrega OT. Outpatient treatment of sleep disorders in Alzheimer patients. Einstein (São Paulo) [Internet]. 2015 [acesso em 03 jun. 2018];13(3):430-4.

Disponível em: https://www.ncbi.nlm.nih.gov/ pubmed/25946052

10. Neumann SMF, Dias CMSB. Doença de Alzheimer: o que muda na vida do familiar cuidador? Rev Psicol Saúde [Internet]. 2013 [acesso em 03 jun. 2018];5(1):10-7. Disponível em: http://pepsic.bvsalud. org/scielo.php?script=sci_arttext\&pid=\$2177093X2013000100003

11. Fonseca VA, Borges MMMC. Doença de Alzheimer: repercussões na vida do cuidador e da família. Rev Enferm Integr [Internet]. 2014 [acesso em 07 jun. 2018];7(2):1262-71. Disponível em: https://www. unilestemg.br/enfermagemintegrada/artigo/v7_2/02doenca-de-alzheimer-repercussoes-na-vida-docuidador-e-da-familia.pdf

12. Goes VF, Carpes PBM, Oliveira LO, Hack J, Magro M, Bonini JS. Avaliação do risco de disfagia, estado nutricional e ingestão calórica em idosos com Alzheimer. Rev Latinoam Enferm [Internet]. 2014 [acesso em 03 jun. 2018]; 22(3):317-24. Disponível em: https://www.revistas.usp.br/rlae/article/ view/85068/87927

13. Cardoso S, Neto OD. Considerações sobre a repetição no idoso com Alzheimer: uma perspectiva psicanalítica. Rev Subj [Internet]. 2016 [acesso em 03 jun. 2018];16(3):1-12. Disponível em: http:// periodicos.unifor.br/rmes/article/view/5120

14. Woellner SS, Araújo AGS, Risso PR, Hoepfer Jr H. Estudo comparativo da mobilidade orientada pelo desempenho em idosos com e sem doença de Alzheimer. Rev Bras Med [Internet]. 2012 [acesso em 03 jun. 2018];69(11):1-5. Disponível em: http://www.moreirajr.com.br/revistas.asp?id_ materia $=5257 \&$ fase $=$ imprime

15. Lopes RA, Mitre NCD, Coelho MAGM, Queiroz BZ. Perfil dos cuidadores das instituições de longa permanência para idosos de Itaúna-MG. Conscientiae Saúde [Internet]. 2012 [acesso em 10 jun. 2018];11(2):338-44. Disponível: http://www.redalyc. org/articulo.oa?id=92923674019

16. Souza IP, Santos LM, Santana VS, Feitosa AG. Capacidade funcional de idosos com Doença de Alzheimer e Parkinson: revisão bibliográfica. Rev Pesqui Fisioter [Internet]. 2014 [acesso em 13 out. 2017];4(1):78-84. Disponível em: https://www5. bahiana.edu.br/index.php/fisioterapia/article/view/377 
17. Ilha S, Santos SSC, Backes DS, Barros EJL, Pelzer MT, Oliveira AMN. (Geronto) Tecnologia cuidativo-educacional na doença de Alzheimer e no apoio ao idoso/família: perspectiva dos docentes e discentes. Esc Anna Nery Rev Enferm [Internet]. 2017 [acesso em 10 jun. 2018];21(2):1-12. Disponível em: http://www.scielo.br/scielo.php?pid=S141481452017000200211\&script=sci_abstract\&tlng=pt

18. Nietsche EA, Lima MGR, Soler RMG, Teixeira JA, Oliveira BNB, Motta CA, et al. Tecnologias inovadoras do cuidado em enfermagem. Rev Enferm UFSM [Internet]. 2012 [acesso em 27 nov. 2017];2(1):182-9. Disponível em: https://periodicos. ufsm.br/reufsm/article/view/3591/3144

19. Mehry EE, Onoko R. Agir em saúde: um desafio para o público. São Paulo: Hucitec; 2002

20. Almeida AP, Bezerra ACP, Vieira GADC, Moreira, Castro LHP, Costa NF. Úlceras por pressão na população idosa brasileira: uma revisão sistemática. In: Anais do $4^{\circ}$ Congresso Internacional de Envelhecimento Humano [Internet]; 24-26 nov. 2015; Campina Grande. Campina Grande: Realize; 2015 [acesso em 10 jun. 2018]. p.1-6. Disponível em: http://www.editorarealize.com.br/revistas/cieh/ trabalhos/TRABALHO_EV040_MD4_SA2_ ID1228_27082015183332.pdf

21. Santos MD, Borges SM. Percepção da funcionalidade nas fases leve e moderada da doença de Alzheimer: visão do paciente e seu cuidador. Rev Bras Geriatr Gerontol [Internet]. 2015 [acesso em 20 set. 2017];18(2):339-49. Disponível em: http://www. scielo.br/scielo.php?script=sci_arttext\&pid=S180998232015000200339\&lng=pt\&tlng=pt

22. Koerich MS, Backes DS, Scortegagna HM, Wall ML, Veronese AM, Zeferino MT, et al. Tecnologias de cuidado em saúde e enfermagem e suas perspectivas filosóficas. Texto \& Contexto Enferm [Internet]. 2006 [acesso em 10 jun. 2018];15(Esp):178-85. Disponível em: http://www.scielo.br/pdf/tce/ v15nspe/v15nspea22 